УДК [903.02+738] (477) Херсонес

DOI: https://doi.org/10.33782/eminak2021.1(33).505

\title{
ОРНАМЕНТАЦІЯ ХЕРСОНЕСЬКОЇ КЕРАМІКИ В ЕЛЛІНІСТИЧНИЙ ЧАС (СЕМАНТИКА ТА ПОШИРЕННЯ)
}

\author{
Вікторія Котенко \\ Інститут археології НАН України (Київ, Україна) \\ e-mail: kotenkovikt@gmail.com \\ ORCID: https://orcid.org/0000-0001-9172-1062
}

\begin{abstract}
у статті розглядається столовий посуд, виготовлений у Херсонесі Таврійському в елліністичний час. Досліджується орнаментація виробів, запропоноване можливе трактування семантичного навантаження окремих елементів декору. Припускається взаємозв'язок мотивів розпису та міфологічних сюжетів, які також відобразилися і в інших проявах матеріальної культури полісу. З'ясовуються традиційні прийоми херсонеської орнаментики за доби еллінізму. Простежується поширення херсонеського орнаментованого столового посуду до полісів Північно-Західного Причорномор'я.
\end{abstract}

Ключові слова: елліністичний час, Херсонес Таврійський, кераміка, орнамент, культ

Матеріальна культура полісів Північного Причорномор'я в елліністичний час характеризується широким спектром кераміки, як завезеної 3 віддалених центрів, так і місцевого виробництва. Диспропорція в її вивченні є досить суттєвою - яскраві зразки імпортної кераміки завжди були у пріоритеті дослідницьких пошуків, натомість масовий посуд місцевого виробництва вивчався вибірково. Окремо постає питання поширення кераміки північнопричорноморських полісів у межах регіону, а також власне атрибуція таких виробів у різних центрах.

Поза увагою тривалий час лишалася й семантика розпису кераміки місцевого виробництва, тобто тлумачення образів, застосованих в орнаментальних композиціях деяких виробів. Верифікація колекцій на сучасному етапі дає можливість по-новому поглянути на накопичений матеріал, запропонувати різні підходи до його вивчення. Колекція херсонеської кераміки з полісів Північно-Західного Причорномор'я вже частково була опублікована, однак аспект орнаментації такого посуду розглянуто вперше.

На думку Р.М. Кука, в елліністичний час простежується повсюдна деградація античного вазопису, а орнаменти цього часу взагалі не варто виокремлювати в окремий стильํ. Але, попри таку фіксацію мистецької кризи у добу еллінізму, варто зазначити, що в цей час розпис столового посуду у Північному Причорномор'ї - парадного та буденного, імпортного та місцевого - все ж був популярним і представлений переважно рослинними мотивами. Ув'язка між собою різних аспектів матеріальної та духовної культури (гончарства і художнього розпису) можлива, передусім, завдяки відомим згадкам флори у міфологічних сюжетах давніх греків, де $\epsilon$ прямі асоціації рослин з героями, і тому вони можуть бути співставленні з певними орнаментами. Як відомо, життя і світогляд еллінів були тісно пов'язані з природою, їм був притаманний глибокий символізм. Грецька філософія, а відтак і мистецтво, відображене у матеріальній культурі, по відношенню до

1 Cook R.M. Greek Painted Pottery. London, New York: Routledge, 1997. P. 193. 
природи була результатом безпосереднього споглядання, природа ще аналізувалася та сприймалася як єдине ціле. Рослини були невід'ємним атрибутом грецького побуту: окрім культивування сільськогосподарських культур, рослини використовували у медицині, вони були головним компонентом у приготуванні ефірних олій і пахощів, основою деяких барвників тощо. Крім того, вінками та гілками різних рослин було прийнято прикрашати храмові будівлі, причому у суворій залежності від того, кому вони були присвячені².

Одним з потужних центрів виробництва кераміки елліністичного часу був Херсонес Таврійський, де археологічно зафіксовано район з випалювальними печами ${ }^{3}$. Більш того, факт виготовлення розписного посуду у місцевих ергастеріях було зафіксовано археологічно ${ }^{4}$ Масштабні об'єми розвитку гончарства дозволили полісу забезпечити глиняним посудом низку поселень у Північно-Західній Тавриці, через які розвивався один з пріоритетних векторів херсонеської економіки до полісів Північно-Західного Причорномор'я. Як і амфори Херсонеса Таврійського, місцевий столовий посуд відноситься до так званої групи «червоноглиняної» кераміки, у формувальній масі якої помітні включення вапняку й інші домішки. Морфологія такого посуду теж цілком упізнавана - це численні миски, столові глеки, переважно видовжених пропорцій, фляги й інше. 3-поміж них особливої уваги заслуговують орнаментовані вироби, які $є$ частиною античної культури Північного Причорномор'я.

«Візитною карткою» херсонеської кераміки елліністичного часу $є$ розпис у вигляді оперізуючих смуг (або концентричних - на флягах), виконаний темночервоною фарбою, ймовірно мінерального походження (рис. 1.1). У деяких випадках орнамент наносився поверх світлого ангобу або ж були присутні й смуги білої фарби, особливо по горлу глека. Вироби, орнаментовані у такий спосіб, переважають у масиві кераміки з Херсонеса Таврійського та на поселеннях його хори й зустрічаються далеко за межами поліса. На всіх, без перебільшення, досліджених античних пам'ятках Північно-Західної Таврики відома така кераміка, яка за масовістю та відомими аналогами з центру поліса відноситься до місцевої, тобто херсонеської ${ }^{5}$.

3 мистецтвознавчої точки зору, лінії (або стрічки), паралельні основі, у даному випадку денця (плаского або на кільцевому піддоні), створюють візуальний ефект «стійкості». Сам же спосіб нанесення оперізуючих смуг на опуклу поверхню - це спосіб досягти гармонії пропорції, адже декор краще співпадає з формою предмета, коли її підкреслює ${ }^{6}$. Нанесення ліній різної товщини, переважно на тулуб посудини у найширшій його частині, зустрічається ще на кераміці геометрич-

\footnotetext{
2 Скржинская М.В. Культурные традиции Эллады в античных государствах Северного Причерноморья. Киев: Институт истории Украины, 2010. С. 250.

3 Кузнецова Е.В. О гончарных мастерских Херсонеса Таврического, исследованных В.В. Борисовой // Записки Института истории материальной культуры РАН. 2017. № 16. С. 118-127.

${ }^{4}$ Борисова В.В. Гончарные мастерские Херсонеса (по материалам раскопок 1955-1957 гг.) // Советская археология. 1958. № 4. С. 150, рис. 7.

${ }^{5}$ Кутайсов В.А. Уженцев В.Б. Восточные ворота Калос Лимена // Северо-Западный Крым в античную эпоху. Киев, 1994. С. 63, рис. 14, 4; Егорова Т.В. Новая раннеэллинистическая усадьба на городище «Чайка» и ее место в структуре поселения // Stratum plus. 2014. № 3. С. 318, рис. 18, 1; Котенко В.В. Елліністичні глеки з поселення Маслини // Археологія. 2015. № 3. С. 84.

6 Моран А. История декоративно-прикладного искусства от древнейших времен до наших дней. Москва: Искусство, 1982. С. 12.
} 
ного стилю, тому витоки ідеї такого мінімалізму складно шукати у конкретній епосі.

Щодо Херсонеса Таврійського, то «смугаста» кераміка тут відома і в імпортних матеріалах пізньої класики. Хронологічно близький іонійський посуд можливо й впливав на тенденції у декорі херсонеської місцевої кераміки, однак цей вплив навряд можна вважати вирішальним. 3 одного боку, існує точка зору про так звані ремінісценції іонійських виробів в гончарному виробництві Херсонеса Таврійського7, однак фактично їх побутування не було домінуючим 8 , як це помітно за комплексом матеріалів елліністичного часу. Як дозволяють стверджувати спостереження за гончарним процесом, такий орнамент відзначається простоту нанесення - пензлем з фарбою по глечику, що обертається. Саме тому він, очевидно, є дуже поширеним у часі та просторі, але особливо відчутно відбився саме на матеріалах місцевої херсонеської кераміки другої половини IV - середини II ст. до н.е.

Дещо більше можна сказати про херсонеську кераміку, прикрашену рослинними орнаментами. Як відомо, флористичні мотиви були органічно включені у міфологічні сюжети еллінів, їх глибока семантика нині добре досліджена і символізм цих образів цілком можна перенести у практичну площину дослідження кераміки. Червоноглиняні глеки херсонеського виробництва часто прикрашалися розписом червоною фарбою у вигляді гілочок винограду, лавру, плюща чи набігаючої хвилі. Як вдалося з'ясувати ${ }^{9}$, окрім Херсонеса Таврійського та його хори, така кераміка відома в Ольвії, Тірі, Ніконії, не виключено її потрапляння разом 3 амфорами і в задунайські поліси. Зокрема, західна межа поширення такого типу кераміки визначається дослідниками Каллатісом, Томами та Істрією, де їі детально досліджено ${ }^{10}$.

Стилістично такий орнамент відносять до місцевої ремінісценції Гадри, як це, наприклад, відомо за матеріалами Істрії та сусідніх полісів. Названий такий стиль за епонімною пам'яткою - військового некрополя в Александрії Єгипетській, відкритого наприкінці XIX ст.11 Урни, в яких містилися кремації, були пишно декоровані стилізованими флористичними зображеннями. Дослідження цієї колекції вже має свою історію, особливо епіграфічна складова ${ }^{12}$. А стилістичні особливості гідрій з Александрії стали основою одного з типів розписної елліністичної кераміки ${ }^{13}$. Темною фарбою, переважно на світлому тлі посудини, були розписані по тулубу та по горлу гілочками різних рослин. Візуально такий декор нагадує стиль Західного схилу, відомий за матеріалами чорнолакового посуду. Але, не-

\footnotetext{
7 Лесная Е.С. Имитации некоторых форм восточногреческой столовой керамики из раскопок Херсонеса // Боспорский феномен. Общее и особенное в историко-культурном пространстве античного мира. Материалы международной научной конференции. Ч. 2. Санкт-Петербург, 2018. С. 6466.

8 Буйских А.В. Херсонес Таврический в VI в. до н.э.: реальность историческая или археологическая? // Античный мир и археология (Саратов). 2006. № 12. С. 274.

9 Котенко В.В. Херсонеський керамічний імпорт до Північно-Західного Причорномор'я // I Всеукраїнський археологічний з'їзд. Програма роботи та анотації доповідей. (Ніжин, 23-25 листопада 2018 р.). Київ, 2018. С. 117.

${ }^{10}$ Lungu V., Dupont P. Imports and Local Imitations of Hellenistic Pottery in the Northwest Black Sea Area: Hadra and Pseudo-Hadra Wares // Black Sea Studies. Aarhus, 2014. № 16. P. 233-254.

${ }_{11}$ Cook B.F. Inscribed Hadra Vases in the Metropolitan Museum of Art // The Metropolitan Museum of Art (New York). 1966. № 12. P. 7-12.

12 Cook B.F. Inscribed Hadra Vases... P. 12-18.

13 Cook R.M. Greek Painted Pottery... P. 197-198.
} 
зважаючи на схожість херсонеського розпису з Гадрою, можна припустити, що місцеві причорноморські вазописці піддалися лише технічно середземноморському культурному впливу, вкладаючи в орнаменти власне значення.

Найпоширенішим з рослинних орнаментів були завитки, які трактуються як зображення плюща, що плететься ${ }^{14}$, або ж як образ ампелосу - виноградної лози, завитків молодого винограду (рис. 1.2). Виноградарство було стратегічно важливим промислом в економіці давніх греків, а власне Херсонес Таврійський був потужним виробником й імпортером вина у Північному Причорномор'ї. Зокрема, за підрахунками, п'ята частина всього виробництва херсонеського вина в якості імпорту надходила до Ольвії15. Відомо, що у грецькій міфології виноград асоціювався з богом Діонісом, який дав людям першу виноградну лозу і навчив виноробству. 3 виноградом також пов'язані міфологічні сюжети про перетворення на лозу Ампелоса - супутника Діоніса ${ }^{16}$, а також Амброзії - однієї з його менад, ампелосом (виноградною лозою) була також одна із німф-гамадріад ${ }^{17}$. У Херсонесі культ Діоніса був досить популярним. Попри те, що локалізувати храм Діоніса у межах міста дослідникам не вдалося, але все ж, за писемними джерелами, вшанування цього божества передбачало проведення свят і приношення вотивів 18 .

Окрім цього, з виноробством був також пов'язаний культ Геракла, який у межах Північного Причорномор'я набув значної популярності саме в Херсонесі Таврійському, де він отримав статусу полісного, та на поселеннях його хори ${ }^{19} .3$ пам'яток Північно-Західної Таврики відома серія рельєфів із зображенням Геракла (Саки, Чайка, Мойнаки), а форма палиці героя присутня у серії клейм на амфорах херсонеського виробництва 20 . Про це переконливо свідчать й інші категорії археологічних джерел. Кераміка, розписана у такий манер, широко відома як у межах самого городища 21 , так і на поселеннях хори. Більше того, вона представлена обмеженою серією у матеріалах Ольвії 22 , Тіри 23 , Ніконія 24 . Таким чином, розпис у вигляді виноградної лози - ампелос - на глеках херсонеського виробництва тематично поєднується з популярними в елліністичний час культами у цьому полісі - Діоніса та Геракла.

3 Діонісом можна також співставити зображення плюща (кісоса), який, за писемними джерелами, є невід'ємним атрибутом божества 3 дитинства ${ }^{25}$. Його зоб-

14 Lungu V., Dupont P. Imports and Local Imitations... P. 239-240.

15 Зубарь В.М. Херсонес Таврический в античную эпоху. Киев: Наукова думка, 1993. С. 51.

${ }^{16}$ Nonnus, Dionysiaca 11.

${ }^{17}$ Athenaeus, Deipnosophistae 1. 78a.

18 Шевченко Т.М. Релігійний світогляд населення античного Херсонеса. Київ: IA НАНУ, 2011.

C. 135.

19 Шевченко Т.М. Релігійний світогляд населення... С. 74-75.

20 Латышева В.А. Новые данные о культе Геракла в Херсонесе и некоторые аспекты его почитания // Античный мир. Византия: К 70-летию профессора Владимира Ивановича Кадеева. Харьков, 1997. С. 114, рис. 1.

21 Zolotarev M.I. Hellenistic Ceramic Deposit from the North-Eastern Sector of Chersonesos // Black Sea Studies. Aarhus. 2005. № 3. P. 193-216.

22 Котенко В.В. Посуд Херсонеса Таврійського, знайдений в Ольвії // Археологія і давня історія України. 2015. Вип. 1 (14). С. 119-130.

${ }_{23}$ Котенко В.В. Про один із векторів херсонеської торгівлі // Археологія. 2017. № 1. С. 17-23.

24 Котенко В.В. До питання про економічні зв'язки елліністичного Херсонеса з Ніконієм (за керамічними матеріалами) // Античный Никоний и мир племен Северо-Западного Причерноморья. Материалы «круглого стола», посвящённого юбилею Н.М. Секерской и 60-летию начала раскопок Никония (Одесса, 18 мая 2017 г.). Одесса, 2018. С. 17-24.

25 Ovid, Fasti 3. 
раження характеризується присутністю специфічних листочків плюща у вигляді серця (рис. 1.3). Плющева гірлянда широко відома також в орнаментації кераміки стилю Західного схилу, яка була популярна в елліністичному середовищі.

Інший мотив візуально близький до зображення гілочки лавру в період цвітіння (рис. 1.4). Тонкі, парні листочки, що симетрично розміщені відносно центрального пагону, зображувалися на столових глеках - переважно у горловій частині. Крапочками передавався ймовірно цвіт або зав'язь. Лавр, або ж власне Дафна, теж тісно пов'язаний з культовою сферою еллінського світогляду. 3 міфів, наприклад, відомо, що на лаврове дерево була перетворена кохана Аполлона - Дафна2 26 , і з тих пір лавровий вінок - атрибут Аполлона, вручався переможцю Піфійських ігор, що проводилися на його честь. Культ Аполлона був надзвичайно важливим у полісній релігії Херсонеса Таврійського, про що неодноразово наголошено в історіографії, тому зображення лавру на столовому посуді місцевого виробництва не викликає суперечливих думок. Зокрема його вшанування було популярним саме в елліністичний час. Про це свідчать нумізматичні й епіграфічні дані, припускається також наявність певної конструкції для відправлення культу Аполлона на центральній площі Херсонеса27. 3 іншого боку, лаврове дерево семантично пов'язане з богинею Артемідою, володаркою лаврових гаїв, однією 3 супутниць якої власне й була Дафна28. Ступінь популярності цього культу у Херсонеському полісі нині з'ясовується, однак це не зменшує можливої релігійної складової в орнаментальній композиції, де за основу взято лаврову гілку.

Деякі флористичні орнаменти на елліністичних глеках херсонеського виробництва можна ототожнити з гілкою оливи або мирту. Це зображення представлене у вигляді гілки з невеликими заокругленими листочками (рис. 1.5). Зважаючи на економічну значимість культивування оливи, вона звичайно ж мала неабияке значення у культовій сфері еллінів. Будучи безперечно найважливішим деревом у грецькому садівництві, вона згадується у міфі про перемогу Афіни в суперечці за покровительство над Афінами ${ }^{29}$ та в сюжеті про метаморфозу німфи Морії, супутниці Афіни. Отже, найчастіше олива асоціюється саме з Афіною, культ якої у Херсонесі Таврійському був популярним з II ст. до н.е., коли зросла загроза військової присутності в регіоні ${ }^{30}$. Хоча важко говорити саме про таке тлумачення розпису, враховуючи популярність даної рослини в античному світі та її стратегічне економічне значення.

Окрім сюжетів на рослинну тематику, відомі також зображення так званих «вітрувіанських завитків», або «набігаючої хвилі» (рис. 1.6). Поруч з меандром, такий орнамент був широко популярним в еллінській культурі, передусім в архітектурі. У вазописі такі мотиви зустрічаються не часто, однак вони цілком відповідають елліністичній орнаментальній традиції. Прикрашена у такий спосіб кераміка відома з Ольвії31, також яскравим прикладом такого розпису є кратер 3 Овідіопольського поселення 32 . Вважається, що такі хвилі не несли додаткового семантичного навантаження, окрім передачі мариністичного сюжету.

\footnotetext{
26 Ovid, Metamorphoses 1.

27 Шевченко Т.М. Релігійний світогляд населення... С. 138-139.

28 Ovid, Metamorphoses 1.

29 Pseudo-Apollodorus, Bibliotheca 3.14.1

30 Шевченко Т.М. Релігійний світогляд населення... С. 333.

31 Котенко В.В. Посуд Херсонеса Таврійського... С. 121, рис. 1, 6.

32 Сапожников І., Сінельніков О., Котенко В. Орнаментований кратер доби еллінізму: унікальна знахідка з Нижнього Подністров’я // Археологічна керамологія (Опішне). 2019. № 2. С. 37-43.
} 
Орнаменти у вигляді смуг і флористичні зображення, різні за змістом, часто поєднувалися на поверхні однієї посудини, створюючи багату орнаментальну композицію. Здебільшого це були великі столові глеки, площа поверхні яких дозволяла вмістити такий розпис. Умовно центральне місце у композиції найчастіше відводилося ампелосу, завитки якого зображувалися на плечах і в центральній частині тулуба. Схематично смуги та гілки рослин являли собою замкнуте коло, яке символічно можна асоціювати з вінком - неодмінним атрибутом священних істот та елементом святкового убрання елліна. Можливо, певне значення мав і колір розпису - темно-червоний, вохристий, адже така кольорова гама зустрічається на фарбованих теракотах 33 .

Враховуючи той факт, що флористичний розпис зустрічається рідше за «смугастий», можна припустити, що це були парадні посудини, які використовувалися поряд з чорнолаковим посудом. 3 іншого боку, чорнолакових посудин (глеків чи ойнохой) аналогічного об'єму відомо вкрай мало, зокрема на поселеннях херсонеської хори. Також привертає увагу графіті у вигляді монограми на зовнішній поверхні глека (НР) (рис. 1.5), яке традиційно асоціюються з саме з Гераклом, культ якого був популярним у Херсонесі. Цікаво, що серед ольвійських матеріалів такий напис не $\epsilon$ поширеним, у той час як у Херсонесі відомі випадки таких графіті і на чорнолаковому посуді.

Стосовно стилістики такого розпису існує кілька думок. 3 мистецтвознавчої точки зору, орнаменти елліністичного часу не відносяться до жодного з етапів розвитку давньогрецького вазопису. На думку Р.М. Кука, цей час був періодом деградації і тривіальної передачі зображень, які не переслідували реалістичної передачі складних сюжетів 34 . Натомість дослідники Північного Причорномор'я вбачають у таких мотивах глибинні витоки архаїчних мотивів, що органічно поєднувалися з елліністичними елементами. Т.М.Кніпович, аналізуючи розписну кераміку з пам'яток херсонеської хори у Північно-Західній Тавриці, вказує на відродження ранніх стилістичних традицій, які по-новому проявилися в елліністичний час 35 . Не відкидається також культурний вплив середземноморських традицій, а також паралелі з іонійською керамікою. Але, у будь-якому випадку, не варто нехтувати специфікою культурного розвитку полісів Північного Причорномор'я, де панеллінські сюжети майстри могли адаптувати до місцевих особливостей.

Таким чином, дослідження компактної групи кераміки дало можливість через побутові речі прояснити деякі елементи життя понтійських еллінів. Рядова, на перший погляд, орнаментація могла бути пов'язана з релігійною сферою. Про безпосереднє використання такого посуду при вшануванні божеств говорити немає підстав, однак цілком можливо тлумачити такі мотиви у контексті специфіки світогляду херсонеситів і мешканців інших полісів. Досить цікавим виявився момент співставлення семантики рослин 3 простеженими херсонеськими культами. Діоніс, Геракл, Аполлон, Афіна за низкою археологічних та епіграфічних джерел мали важливе значення у культовому житті поліса, і саме символи цих священних істот зображено на кераміці херсонеського виробництва. По-

\footnotetext{
33 Шевченко Т.М., Котенко В.В. Теракоти з поселення Маслини хори Херсонеса Таврійського // Археологія. 2019. № 3. С. 29.

${ }^{34}$ Cook R.M. Greek Painted Pottery... P. 193.

35 Книпович Т.Н. Из истории художественной керамики Северного Причерноморья // Советская археология. Москва-Ленинград, 1941. Вып. VII. С. 148-149.
} 
дальше дослідження орнаментальних композицій дозволить доповнити таку інформацію.

\section{REFERENCES}

Borisova, V.V. (1958). Goncharnye masterskie Khersonesa (po materialam raskopok 1955-1957 gg.) [Pottery workshops of Chersonesos (on excavations of 1955-1957)]. Sovetskaia arkheologiia, 4, 144153 [in Russian].

Buiskikh, A.V. (2006). Khersones Tavricheskii v VIv. do n.e.: realnost' istoricheskaia ili arkheologicheskaia? [Tauric Chersonesos in the $4^{\text {th }}$ century BC: historical or archaeological reality?]. Antichnyi mir i arkheologiia, 12, 263-277 [in Russian].

Cook, B.F. (1966). Inscribed Hadra Vases in the Metropolitan Museum of Art. The Metropolitan Museum of Art, 12.

Cook, R.M. (1997). Greek Painted Pottery. London and New York.

Egorova, T.V. (2014). Novaia ranneellinisticheskaia usadba na gorodishche «Chaika» i eyo mesto v strukture poseleniia [The new Early Hellenistic Farmstead on «Chaika» settlement and its place in its structure]. Stratum plus, 3, 303-323 [in Russian].

Knipovich, T.N. (1941). Iz istorii khudozhestvennoi keramiki Severnogo Prichernomoria [From the history of art ceramics in the Northern Black Sea Region]. Sovetskaia arkheologiia, VII, 140-151 [in Russian].

Kotenko, V.V. (2015). Ellinistychni hleky z poselennia Maslyny [Hellenistic jugs from Maslyny settlement]. Arkheolohiia, 3, 78-87 [in Ukrainian].

Kotenko, V.V. (2015). Posud Khersonesa Tavriiskoho, znaidenyi v Olvii [Ware of Tauric Chersonesos found in Olbia]. Arkheolohiia i davnia istoriia Ukrainy, 1 (14), 119-130 [in Ukrainian].

Kotenko, V.V. (2017). Pro odyn iz vektoriv khersoneskoi torhivli [On one of trade vectors in Chersonesos]. Arkheolohiia, 1, 17-23 [in Ukrainian].

Kotenko, V.V. (2018). Do pytannia pro ekonomichni zviazky ellinistychnoho Khersonesa z Nikoniiem (za keramichnymy materialamy) [To the economic relations between Hellenistic Chersonesos and Niconium (on the ceramic materials)] In Bruiako, I.V. \& Glavenchuk, A.V. (Eds.). Antichnyi Nikonii i mir plemen Severo-Zapadnogo Prichernomoria. Odessa, pp. 17-24 [in Ukrainian].

Kotenko, V.V. (2018). Khersoneskyi keramichnyi import do Pivnichno-Zakhidnoho Prychornomoria [Chersonesan ceramic import to the Northernwest Black Sea Region]. In Chabai, V.P. (Ed.). I Vseukrainskyi arkheolohichnyi zyizd. Kyiv, p. 117 [in Ukrainian].

Kuznetsova, E.V. (2017). O goncharnykh masterskikh Khersonesa Tavricheskogo, issledovannykh V.V. Borisovoi [About the pottery workshops of Tauric Chersonesos, investigated by V.V. Borisova]. Zapiski Instituta istorii materialnoi kultury RAN, 16, 118-127 [in Russian].

Kutaisov, V.A. \& Uzhentsev, V.B. (1994). Vostochnye vorota Kalos Limena [The East Gate of Kalos Limen]. In: Kutaisov, V.A. (Ed.). Severo-Zapadnyi Krym v antichnuiu epokhu. Kiev, pp. 44-70 [in Russian].

Latysheva, V.A. (1997). Novye dannye o kulte Gerakla v Khersonese i nekotorye aspekty ego pochitaniia [New data on the cult of Heracles in Chersonesos and some aspects of his worship]. In: Meshcheriakov, V.F. (Ed.). Antichnyi mir. Vizantiia. K 70-letiiu professora Vladimira Ivanovicha Kadeeva. Kharkov, pp. 114-122 [in Russian].

Lesnaia, E.S. (2018). Imitatsii nekotorykh form vostochnogrecheskoi stolovoi keramiki iz raskopok Khersonesa [Imitations of some forms of Eastern Greek tableware from the excavation of Chersonesos]. In: Zuev, V.Yu. \& Khrshanovskii, V.A. (Eds.). Proceedings of the Conference: Bosporskii fenomen. Obshchee i osobennoe v istoriko-kulturnom prostranstve antichnogo mira, (Vol. 2, pp. 61-67). Sankt-Peterburg [in Russian].

Lungu, V. \& Dupont, P. (2014). Imports and Local Imitations of Hellenistic Pottery in the Northwest Black Sea Area: Hadra and Pseudo-Hadra Wares. Black Sea Studies, 16, 233-254.

Moran A. (1982). Istoriia dekorativno-prikladnogo iskusstva ot drevneishikh vremen do nashikh dnei [The history of arts and crafts from ancient times to the present day]. Moskva [in Russian].

Sapozhnykov, I., Sinelnikov, 0. \& Kotenko, V. (2019). Ornamentovanyi krater doby ellinizmu: unikalna znakhidka z Nyzhnoho Podnistrov'ia [Ornamented crater of the Hellenistic era: a unique find from the Lower Transnistria]. Arkheolohichna keramolohiia, 2, 37-43 [in Ukrainian].

Shevchenko, T.M. (2011). Relihiinyi svitohliad naselennia antychnoho Khersonesa [Religious outlook of the Ancient Chersonesos Habitants]. Kyiv [in Ukrainian].

Shevchenko, T.M. \& Kotenko, V.V. (2019). Terakoty z poselennia Maslyny khory Khersonesa Tavri- 
iskoho [Terracottas from Maslyny settlement at the chora of Tauric Chersonesos]. Arkheolohiia, 3, 19-39 [in Ukrainian].

Skrzhinskaia, M.V. (2010). Kulturnye traditsii Ellady v antichnykh gosudarstvakh Severnogo Prichernomoria [Cultural traditions of Hellas in the ancient states of the Northern Black Sea]. Kiev [in Russian].

Zolotarev, M.I. (2005). Hellenistic Ceramic Deposit from the North-Eastern Sector of Chersonesos. Black Sea Studies, 3, 193-216.

Zubar, V.M. (1993). Khersones Tavricheskii v antichnuiu epokhu [Tauric Chersonesos in Ancient time]. Kiev [in Russian].

\section{Viktoriia Kotenko}

(Institute of Archaeology National Academy of Sciences of Ukraine, Kyiv, Ukraine)

e-mail: kotenkovikt@gmail.com

ORCID: https://orcid.org/0000-0001-9172-1062

\section{Ornamentation of Chersonesan Ceramics in Hellenistic Times (Semantics and Spreading)}

The tableware made in Tauric Chersonese, which was ornamented in different ways, is studied in the paper. Due to the stylistic peculiarities of such painting, it has become possible to trace the spread of ceramics of this type to remote poleis of the North-Western Black Sea region. An attempt is made to disclose the semantic load of certain elements of decor that could be linked with the cult sphere of the Greeks. The importance of comparing archaeological materials with information about the main revered deities in Hellenistic Chersonese is emphasized.

The first, most massive, group of ceramics is represented by table jars with ornamentation in the form of red girdle strips, mainly on the upper part of the vessel. Strips of different thicknesses were applied to the rough surface or over a light engobe. Image of such stripes hardly had a deep symbolic meaning, because it was the ease of application that favoured its mass reproduction. The second group consists of jars with a painting in the form of sprigs or plant garlands. Motif in the form of tendrils of grapes (ampelos) is associated with the significant development of winemaking in Hellenistic Chersonese, as well as with the spread of the cults of Dionysus and Heracles, with which this plant is associated according to written sources. Image of ivy leaves, which is often present in ancient iconography, is also possible to attribute to Dionysus. The third group comprises jars with a painting in the form of sprigs of laurel, which was traditionally an attribute of Apollo. His cult was also present in Tauric Chersonese as one of the most important. Another group of images is represented by olive branches. It is known from mythological creative works that it was associated, first of all, with Athena, who was revered in the polis because of the military threat. Although other interpretations of such an image are not excluded. Among other motifs, there are various curls, waves, and other elements typical for Hellenic arts and crafts.

The issues considered in the work give rise to study more deeply the Hellenistic painted ceramics of Tauric Chersonese and its spreading in the Northern Black Sea region.

Keywords: Hellenistic time, Tauric Chersonese, ceramics, ornament, cult 

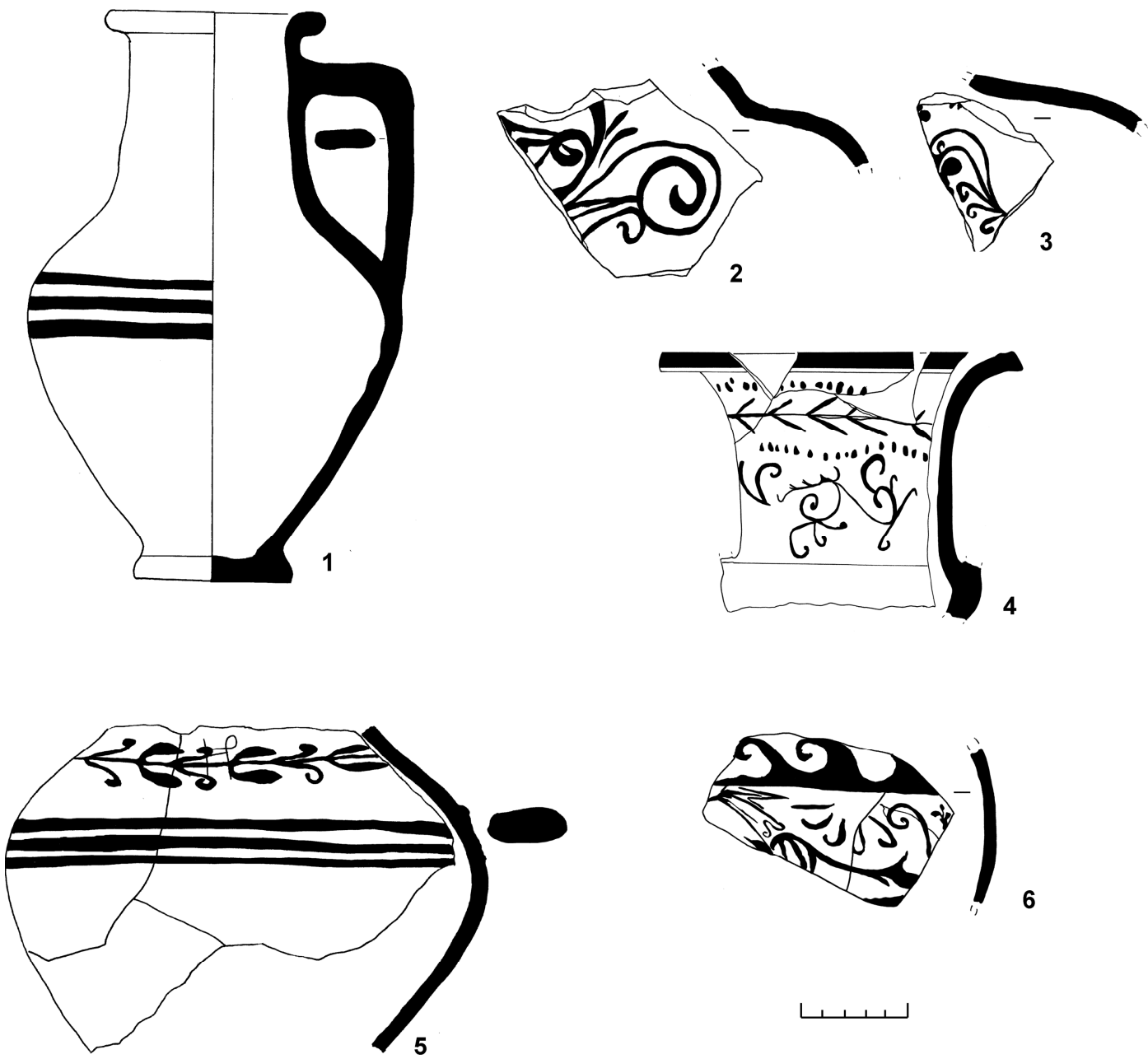

Рис. 1. Типи орнаментів херсонеського столового посуду: 1, 4 - поселення Маслини; 2, 3, 5, 6 - Ольвія. 